\title{
Drought-influenced mortality of tree species with different predawn leaf water dynamics in a decade-long study of a central US forest
}

\author{
L. Gu${ }^{1}$, S. G. Pallardy ${ }^{2}$, K. P. Hosman ${ }^{2}$, and Y. Sun $^{3}$ \\ ${ }^{1}$ Environmental Sciences Division and Climate Change Science Institute, Oak Ridge National Laboratory, \\ Oak Ridge, TN, USA \\ ${ }^{2}$ Department of Forestry, University of Missouri, Columbia, MO 65211, USA \\ ${ }^{3}$ Department of Geological Sciences, University of Texas at Austin, Austin, TX 78712, USA \\ Correspondence to: L. Gu (lianhong-gu@ornl.gov)
}

Received: 5 January 2015 - Published in Biogeosciences Discuss.: 19 January 2015

Revised: 18 April 2015 - Accepted: 21 April 2015 - Published: 18 May 2015

\begin{abstract}
Using decade-long continuous observations of tree mortality and predawn leaf water potential $\left(\psi_{\mathrm{pd}}\right)$ at the Missouri Ozark AmeriFlux (MOFLUX) site, we studied how the mortality of important tree species varied and how such variations may be predicted. Water stress determined interannual variations in tree mortality with a time delay of 1 year or more, which was correlated fairly tightly with a number of quantitative predictors formulated based on $\psi_{\mathrm{pd}}$ and precipitation regimes. Predictors based on temperature and vapor pressure deficit anomalies worked reasonably well, particularly for moderate droughts. The exceptional drought of the year 2012 drastically increased the mortality of all species, including drought-tolerant oaks, in the subsequent year. The drought-influenced tree mortality was related to the species position along the spectrum of $\psi_{\mathrm{pd}}$ regulation capacity with those in either ends of the spectrum being associated with elevated risk of death. Regardless of species and drought intensity, the $\psi_{\mathrm{pd}}$ of all species recovered rapidly after sufficiently intense rain events in all droughts. This result, together with a lack of immediate leaf and branch desiccation, suggests an absence of catastrophic hydraulic disconnection in the xylem and that tree death was caused by significant but indirect effects. Species differences in the capacity of regulating $\psi_{\mathrm{pd}}$ and its temporal integral were magnified under moderate drought intensities but diminished towards wet and dry extremes. Severe droughts may overwhelm the capacity of even drought-tolerant species to maintain differential levels of water potential as the soil becomes exhausted of available water in the rooting zone, thus rendering them more susceptible to death if predisposed by other factors such as age.
\end{abstract}

\section{Introduction}

The world's forests are currently a large carbon sink (Pan et al., 2011), helping curtail the rising of atmospheric $\mathrm{CO}_{2}$ concentrations due to anthropogenic emissions. This present carbon sink, however, is vulnerable to factors that can alter forest structure and function. Among such factors, tree mortality influenced by drought has been increasingly of concern (Allen et al., 2010). In many regions of the world, droughtinfluenced tree mortality is believed to be accelerating (Peng et al., 2011; van Mantgem et al., 2011). Whether this acceleration is related to global and regional climate warming caused by fossil $\mathrm{CO}_{2}$ emissions is uncertain. However, climate warming is expected to lead to a drier land surface (Sherwood and Fu, 2014) and faster developing pace and elevated intensity of drought even if it may not directly result in a higher frequency of drought (Trenberth et al., 2014; Cook et al., 2015). Thus, understanding and being able to predict drought-influenced tree mortality are essential to assessing the sustainability of the world's forests as a carbon sink if the climate system warms as expected (Xu et al., 2013; McDowell et al., 2013a).

It is a challenge to understand and predict tree mortality in general and drought-influenced tree mortality in particular. Drought may result in or contribute to tree death in multiple ways. Total hydraulic disconnection (catastrophic xylem cavitation causing complete loss of hydraulic conductivity and leading to rapid shoot desiccation and death) is not uncommon in shallowly rooted seedlings (e.g., Williams et al., 1997). Although such complete hydraulic dysfunction is 
difficult to demonstrate in mature plants, partial loss of hydraulic function and carbon starvation (stomatal closure to avoid hydraulic disconnection and protect the photosynthetic machinery resulting in reduced photosynthesis and negative plant carbon balance) have also been advanced as agents of tree death from drought (McDowell et al., 2008; Hoffmann et al., 2011; Anderegg et al., 2013, 2014; Nardini et al., 2013). These different mechanisms do not necessarily operate independently (McDowell, 2011; McDowell et al., 2013b; Sevanto et al., 2014). Furthermore, they might not be the proximate cause of death; for example, they may simply weaken the trees by decreasing or preventing defensive chemical production and thus predispose the trees to attacks by insects, pathogens and fires which eventually cause death (Waring, 1987; McDowell, 2011; Pratt et al., 2014). Additionally, the literature in this area is complicated by recent reports that techniques of hydraulic conductivity measurement in many previous studies overestimate xylem cavitation and increasingly so as xylem tension increases (e.g., Wheeler et al., 2013; Rockwell et al., 2014; Cochard et al., 2015), effects which may provide erroneous vulnerability curves and spurious evidence of xylem refilling. Hence, other approaches relating drought-related mortality to plant water relations may be useful.

Maintenance of plant function and short-term viability under meteorological drought is determined by many traits, including the capacities for restriction of water loss from shoots, efficient water transport from roots to shoots, robust root system architecture and capacity, as well as plant capacity to tolerate dehydration (Kozlowski and Pallardy, 2002). Drought-tolerant tree species generally possess some nexus of traits that promotes continued carbon fixation as a drought progresses (e.g., access to deep soil water supplies, osmotic adjustment, delayed stomatal closure, a robust photosynthetic apparatus, maintenance of xylem function) (Hinckley et al., 1981; Bahari et al., 1985; Abrams, 1990; Kubiske and Abrams, 1994) but at the same time confers sufficient cellular dehydration tolerance capacity to survive substantial water deficits (Ludlow, 1989; Martin et al., 1987). Investigating how species with varying expression of these traits survive over the mid to long term under natural cycles of drought, and developing potential predictors of performance at such timescales, would be valuable in deepening understanding of the nature of drought tolerance and modeling of mortality under drought.

We have been monitoring the mortality of tree species at the Missouri Ozark AmeriFlux (MOFLUX) site since 2005 and predawn leaf water potential $\left(\psi_{\text {pd }}\right)$ since 2004 (Gu et al., 2006, 2007; Yang et al., 2009). The different tree species monitored at the MOFLUX site exhibited a range of drought tolerance (see the next sections). During our study period, a wide range of precipitation regimes from abundant rain to extreme drought occurred at the MOFLUX site, resulting in large inter-annual fluctuations in plant water stress levels and associated tree mortality (see the next sections). In particular, several drought events with varying drought intensity occurred during the study period. The 2012 drought was the strongest category D4 (exceptional drought), according to the US Drought Monitor Classification Scheme and offered a contrast to earlier, less severe droughts. The combination of species diversity, relatively long mortality time series, and broad range of precipitation regimes provided a rare opportunity to investigate how drought and precipitation variability affect tree mortality, how such impacts may be related to the physiological adaptations and drought tolerance, and how drought-influenced tree mortality can be predicted effectively. We explore these issues in the present paper.

\section{Materials and methods}

\subsection{Study site}

The study was conducted at the MOFLUX site. The MOFLUX site, which has been operating since 2004 with a suite of meteorological and ecological instrumentation $(\mathrm{Gu}$ et al., 2006, 2007; Yang et al., 2010), is located in the University of Missouri's Baskett Wildlife Research and Edu-

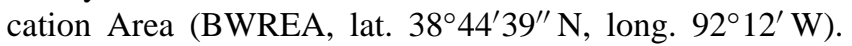
BWREA is within the Ozark border region of central Missouri. Second-growth upland oak-hickory forests constitute the major vegetation type at the BWREA (Rochow, 1972; Pallardy et al., 1988). Major tree species include white oak (Quercus alba L.), black oak (Q. velutina Lam.), shagbark hickory (Carya ovata (Mill.) K. Koch), sugar maple (Acer saccharum Marsh.), and eastern redcedar (Juniperus virginiana L.). Although these species co-occur in MOFLUX forests, there are differences in which species dominate in particular locations. Ecological and physiological studies of these species (e.g., Fralish et al., 1978; Hinckley et al., 1981; Ginter-Whitehouse et al., 1982; McCarthy et al., 1984; Bahari et al., 1985; Martin et al., 1985; Ni and Pallardy 1991, 1992; Pallardy and Rhoads, 1993; Loewenstein and Pallardy, 1998; Abrams, 2003) have shown that white and black oaks and eastern redcedar are more dominant than shagbark hickory and sugar maple in drier habitats and exhibit adaptations promoting better function under drought conditions (e.g., deeper rooting, lower osmotic potentials, greater osmotic adjustment under drought, maintenance of leaf conductance and photosynthesis to lower leaf water potentials, greater leaf dehydration tolerance capacity). White ash (Fraxinus americana L.) is found as a scattered tree in MOFLUX forests and has not been studied as extensively but has been reported to favor sites with high soil water availability (e,g., McCarthy et al., 1984; Schlesinger, 1990; Woodcock et al., 1992).

The climate of the area is warm, humid, and continental (Critchfield, 1966), with monthly mean temperature of $-1.3^{\circ} \mathrm{C}$ in January and $25.2^{\circ} \mathrm{C}$ in July and an annual total precipitation average of $1083 \mathrm{~mm}$ (National Climatic Data Center 1981-2010 climate normals, Columbia Regional Air- 
port, Missouri, about $10 \mathrm{~km}$ to the northwest). Dominant soils at the site are Weller silt loam (Fine, smectitic, mesic Aquertic Chromic Hapludalf) and Clinkenbeard very flaggy clay loam (Clayey-skeletal, mixed, superactive, mesic Typic Argiudoll) (Young et al., 2001). The comparatively thin soils of these oak-hickory forests often exacerbate plant water stress when droughts occur (Bahari et al., 1985; Jenkins and Pallardy, 1995).

\subsection{Measurements}

\subsubsection{Meteorological measurements}

Measurements of precipitation, temperature and relative humidity were made at the top of the $30 \mathrm{~m}$ flux tower and used to formulate potential meteorologically based predictors for tree mortality. Precipitation was measured with a recording tipping bucket rain gauge (TR-525M, Texas Electronics, USA). Data were totaled over 30 min periods. Atmospheric vapor pressure deficit (VPD) was computed from temperature and relative humidity. At the MOFLUX site, routine meteorological measurements are made with plenty of redundant sensors to minimize the risk of measurement gaps.

\subsubsection{Tree mortality monitoring}

Individual trees with diameter at breast height (DBH, $1.3 \mathrm{~m}$ height) larger than $9 \mathrm{~cm}$ were inventoried when the site was established in 2003-2004. The inventory used 24 circular plots, each with a size of 0.08 ha. These plots were placed at $50 \mathrm{~m}$ intervals away from the site flux tower along the southeast ( $n=5$ plots), south $(n=5)$, southwest $(n=5)$, west $(n=5)$ and northwest $(n=4)$ transects. The last transect had only 4 plots as it terminated in a pond. On each plot, living trees were identified with a numbered aluminum tag, identified to species and measured for DBH. In each subsequent year, death of tagged trees was noted and recorded during frequent (at least monthly, during the growing season) visits to all plots.

\subsubsection{Predawn leaf water potential $\left(\psi_{p d}\right)$}

Since early June of 2004, measurements of $\psi_{\text {pd }}$ have been made periodically (weekly to biweekly) during the growing seasons. In each year, except for 2004, the first measurements occurred in mid-May. In all years, the last measurements took place in late October. Leaf samples were collected before dawn for canopy and sapling individuals of common tree species at the site. A total of 20-21 samples were obtained each day with 6-7 taken from Quercus alba, and the rest, with at least two samples per species, distributed among $Q$. velutina, Acer saccharum, Carya ovata, Fraxinus americana $\mathrm{L}$. (white ash), and Juniperus virginiana, roughly in proportion to their relative stem abundance in the stand. $\psi_{\text {pd }}$ was measured with a pressure chamber (Turner, 1981; Pallardy et al., 1991). Leaves or leaflets (both oak species, shagbark hickory and white ash) or shoots (sugar maple and eastern redcedar) were sampled from lower branches $(<2 \mathrm{~m}$ height) thus rendering any gravitational component minimal. After excision with a razor blade, samples were immediately placed in humidified bags in a chest cooler until measurement promptly after sample collection was complete.

\subsection{Potential predictors for tree mortality}

Successful approaches to predicting drought-influenced tree mortality remain elusive in the present and it is beneficial to explore a wide array of possibilities (Hoffmann et al., 2011; Nardini et al., 2013). To take advantage of our relatively long mortality data set and a broad range of meteorological and physiological measurements, we examined a suite of potential predictors for tree mortality. These potential predictors included mean daily precipitation rate $\bar{p}$, predawn leaf water potential integral (PLWPI), precipitation variability index (PVI), mean effective precipitation interval (MEPI), positive temperature anomaly integral (PTAI), and water vapor pressure deficit integral (VPDI). Their definitions and the rationales for applying them to study tree mortality are described below. Our objective was not about determining which index was the best; our mortality data set, although already rare, was still not sufficient for such a task. Rather, we were interested in the potential of these indices as predictors of tree mortality.

\subsubsection{Predawn leaf water potential integral (PLWPI)}

PLWPI is the area between the seasonal curve of the measured $\psi_{\text {pd }}$ and the zero $\psi_{\text {pd }}$ line (Myers, 1988). The seasonal curve is formed by linearly interpolating $\psi_{\text {pd }}$ measurements to days when no measurements are made so that every day in the growing season has either a measured or interpolated $\psi_{\mathrm{pd}}$. Thus PLWPI is simply the summation of $\psi_{\mathrm{pd}}$ over the growing season: PLWPI $=\sum_{i=1}^{n} \psi_{\mathrm{pd}}(i)$, where $\psi_{\mathrm{pd}}(i)$ is the $\psi_{\mathrm{pd}}$ of the $i$ th day in the growing season. Myers (1988) showed that PLWPI provides a link between short-term water stress and long-term plant growth. Hanson et al. (2003) used the soil water potential integral, which is correlated with PLWPI, to indicate forest water stress. PLWPI is a direct, integrative measure of plant water stress over the growing season and can be used as a relative indicator of the overnight capacity of a plant to rehydrate leaves from soil water. PLWPI provides an estimate similar to the "static" component of water stress described by Tyree and Sperry (1988). Species with superior water acquisition capacity should have relatively high (less negative) PLWPI. Hence, species with deeper root distributions should have higher $\psi_{\text {pd }}$ and PLWPI than cooccurring species with shallower roots because surface soil layers dry first. Furthermore, persistent significant loss of stem hydraulic conductivity, if it happens, should be captured in $\psi_{\text {pd }}$ and PLWPI because such appreciable loss of conductivity will delay and/or prevent overnight recovery in leaf wa- 
ter potential of the shoot. Although Tyree and Sperry (1988) included this latter source of stress in the "dynamic" component, in the case of PLWPI it is probably best considered as a component of the "static" contribution because it contributes to lower leaf water potentials whether or not there is any daytime flow in the soil-plant system. Consequently, differences in $\psi_{\text {pd }}$ and PLWPI among species in the same environment reflect their differences in the degree of water stress avoidance capacity. Multi-year measurements of PLWPI and mortality thus allow interesting comparisons among levels of induced water stress, mortality and interspecific variations in these parameters.

\subsubsection{Precipitation variability index (PVI) and mean effective precipitation interval (MEPI)}

Since long-term, continuous $\psi_{\text {pd }}$ and PLWPI measurements are rarely available, it is also desirable to formulate and verify potential predictors of mortality based on routinely measured meteorological variables. Such predictors help put particular droughts within the broader context of precipitation regimes so that impacts of drought on tree mortality can be effectively evaluated. In this study, we used $\bar{p}$, PVI and MEPI to quantify precipitation regimes. PVI is defined as the following:

$\mathrm{PVI}=\sqrt{\frac{\sum_{i=1}^{n}\left(R_{i}-\bar{R}\right)^{2}}{n}}$,

where,

$R_{i}=\frac{C_{i}}{E_{i}}$

$\bar{R}=\frac{\sum_{i=1}^{n} R_{i}}{n}$,

$C_{i}=\sum_{j=1}^{i} p_{j}$,

$E_{i}=i \bar{p}$

Here, $\left\{p_{1}, p_{2}, \ldots, p_{n}\right\}$ is a time series of precipitation measurements and $i=1, \ldots, n$. It is assumed that the values of $p_{i}, i=1, \ldots, n$, are measured at regular intervals. The intervals can be hourly, daily, or weekly, or longer, depending on the intended use of the resultant PVI. For the purpose of this study, we assume that the values of $p_{i}$ are measured daily in a unit of millimeters per day. PVI is dimensionless. It has a value of zero for perfectly uniform precipitation and increases as precipitation events become more sporadic.

To complement PVI, which is strictly an index of variability and does not contain information about precipitation quantity, we used MEPI to incorporate both precipitation variability and quantity into a single measure. MEPI is de- fined as the average of all time intervals during which no precipitation exceeding a threshold daily precipitation rate $\left(p_{\mathrm{t}}\right)$ occurs. It is based on the concept of effective precipitation (Noy-Meir, 1973; Porporato et al., 2002). For a precipitation event to contribute effectively to relieving plant water stress, it has to be sufficiently intense so that it can penetrate the canopy and litter layer to wet the mineral soil. After tests with many threshold values of $p_{\mathrm{t}}$, we found that at the MOFLUX site, MEPI with a $p_{\mathrm{t}}$ of $5 \mathrm{~mm} \mathrm{day}^{-1}$ explained inter-annual variations in plant mortality most effectively. We use MEPI5 to denote MEPI with $p_{\mathrm{t}}=5 \mathrm{~mm}$ day $^{-1}$.

\subsubsection{Positive temperature anomaly integral (PTAI) and water vapor pressure deficit integral (VPDI)}

It has been suggested that temperature and atmospheric VPD may play elevated roles in tree mortality influenced by global change-type droughts (Breshears et al., 2009; Adams et al., 2009; Weiss et al., 2009; Eamus et al., 2013; Williams et al., 2013). To complement the water availability-based potential predictors ( $\bar{p}$, PLWPI, PVI and MEPI5) for tree mortality, we applied PTAI and VPDI in an attempt to capture effects of high temperature and VPD, respectively:

$$
\begin{aligned}
& \mathrm{PTAI}=\sum_{i=1}^{n} \max \left(T_{i}-T_{\mathrm{c} i}, 0\right) / 48, \\
& \mathrm{VPDI}=\sum_{i=1}^{n} \mathrm{VPD}_{i} / 48
\end{aligned}
$$

In Eq. (6), $T_{i}$ is the observed half-hourly temperature at the time step $i$ and $T_{\mathrm{c} i}$ is the daily mean temperature climate normal of the day during which the time step $i$ occurs. "max" in the right-hand side of Eq. (6) means that in any day, only those half-hourly temperatures above the normal of that day (i.e., positive temperature anomaly) are included in the calculation of PTAI and any negative temperature anomaly is replaced by the value of zero in the calculation. The daily mean temperature climate normals were computed by the US National Climatic Data Center (NCDC) with observations of the period 1981-2010 at the Columbia Regional Airport (less than $10 \mathrm{~km}$ to the northwest of the MOFLUX site). The halfhourly temperature data were from measurements made at the top of the MOFLUX tower. In Eq. (7), $\mathrm{VPD}_{i}$ is the vapor pressure deficit in the unit of kilopascals at $i$. The VPD values were half-hourly and computed from half-hourly temperature and relative humidity observed at the top of the tower. The division by 48 in Eqs. (6) and (7) allows PTAI and VPDI to be expressed in units of degrees Celsius per day and kilopascals per day, respectively. The summations are over the growing season.

\subsection{Data processing and analysis}

Mortality data from 2005 to 2014 and measurements of precipitation, $\psi_{\text {pd }}$, temperature and VPD from 2004 to 2013 
were used in this study. For precipitation, $\psi_{\text {pd }}$, temperature and VPD, only growing-season measurements were used. We used days 120 and 300 as the start and end of the growing season, respectively, based on the seasonal patterns of leaf area index (LAI) measured at the site (data not shown). While the onset and senescence of vegetation activities varied somewhat from year to year (which was not found to have any direct effect on tree mortality), using the same dates to mark the growing season for all years eliminated uncertainties in the calculated predictors that may be caused by interannual variations in the length and timing of the growing season. Persistence of snow cover at the MOFLUX site is limited to a few weeks at most in mid-winter and by late April all snow has long melted. We linearly interpolated measurements of $\psi_{\mathrm{pd}}$ for days when predawn measurements were not made. It was assumed that the $\psi_{\text {pd }}$ on days 120 and 300 was zero so that any day before the first (mid-May in every year except for 2004 and early June for 2004) or after the last measurement (late October for all years) could be properly interpolated. This assumption was a reasonable approximation because the first and last measurements of $\psi_{\mathrm{pd}}$ were always close to zero even during years when severe drought occurred (see the Results section).

Because meteorological and physiological measurements started in early June 2004 at the MOFLUX site, there was a measurement gap of about 40 days (days 120-160) in the growing season of 2004. We tested three strategies for dealing with this measurement gap. In the first strategy, we filled the measurement gap with the data from the same period of 2008 to compute the growing-season $\bar{p}$, PVI, MEPI5, PLWPI, PTAI and VPDI in 2004. This strategy was based on the fact that both the years 2004 and 2008 were relatively wet and the measured seasonal variations in $\psi_{\text {pd }}$ of these two years were broadly similar to each other (see the Results section). The second strategy was simply to compute the potential predictors with available data in 2004 while the third was to exclude 2004 from the analysis. All three strategies led to similar findings in terms of how the predictors were related to tree mortality. We reported the results based on the first strategy.

We expressed the mortality of trees $(\mathrm{DBH}>9 \mathrm{~cm})$ in different ways based on the specific requirements of analysis. First, we analyzed the total mortality from 2005 to 2014 for each species within each DBH class. Each DBH class had a width of $6.3 \mathrm{~cm}$ and $10 \mathrm{DBH}$ classes covered all trees sampled. For the DBH-based mortality analysis, the total mortality of each species was expressed as a percentage relative to the total number of dead trees of all species within each DBH class. This total mortality percentage of a species within each DBH class was then compared to this species' relative stand abundance in this DBH class (also a percentage number) in the 2005 forest inventory data. This comparison indicated whether trees of a species died proportionally or disproportionally to its stand abundance.
Second, we analyzed inter-annual variations of species mortality and their relationships with those of $\bar{p}$, PVI, MEPI5, PLWPI, PTAI and VPDI. In this second analysis, DBH classes were not differentiated. The mortality of each species in each year was expressed relative to either the total stem number or the total basal area of this species in the 2005 forest inventory data. The former was termed stem mortality and the latter basal area mortality, all expressed as percentages.

In addition to the mortality analysis at the species level, we also analyzed mortality at the community level. In this case, the community mortality in each year was expressed relative to either the total stem number or the total basal area of the whole stand in the 2005 forest inventory data. A community PLWPI was also calculated, which was the mean of species PLWPI weighted by species relative abundance in the stand.

Simple regressions with only two free parameters were applied for all fittings except for two cases where three were used. This prudent use of free parameters avoided over-fitting the limited mortality data. The Akaike information criterion corrected for finite sample size (AICc; Anderson 2010) was used to select for the most parsimonious model among different orders of polynomials or simply constructed exponential types of function when ambiguity existed as to whether a linear regression was the optimal choice. Once a model was selected, the $R^{2}$ was displayed to show the variance explained and thus the potential of a mortality predictor. The fitting used in-house software that has been developed over the years and supported efforts of parameter estimation such as those of LeafWeb (leafweb.ornl.gov; Gu et al., 2010; Sun et al., 2014)

\section{Results}

\subsection{Inter-annual variations in precipitation regimes and potential meteorologically based predictors of tree mortality}

From 2004 to 2013, potential abiotic predictors of tree mortality varied widely in association with changing precipitation regimes at the MOFLUX site (Fig. 1). Ranked with the mean daily precipitation rate $\bar{p}$ of the growing season, the driest (wettest) and second driest (wettest) growing seasons occurred in 2012 (2008) and 2007 (2009), respectively (Fig. 1a). Although 2012 and 2007 did not differ much in terms of $\bar{p},\left(1.4\right.$ vs. $\left.1.6 \mathrm{~mm} \mathrm{day}^{-1}\right)$, both PVI (Fig. 1b) and MEPI5 (Fig. 1c) were considerably higher in 2012 than in 2007. In addition, the PTAI (Fig. 1d) and VPDI (Fig. 1e) were also higher in 2012 than in 2007. Thus, the growing season of 2012 had not only more variable precipitation but also higher heat stress and atmospheric evaporative demand than that of 2007. This difference had consequences on the tree mortality caused by the droughts of these 2 years. The inter-annual variations in $\bar{p}$, PVI, MEPI5, PTAI and VPDI 

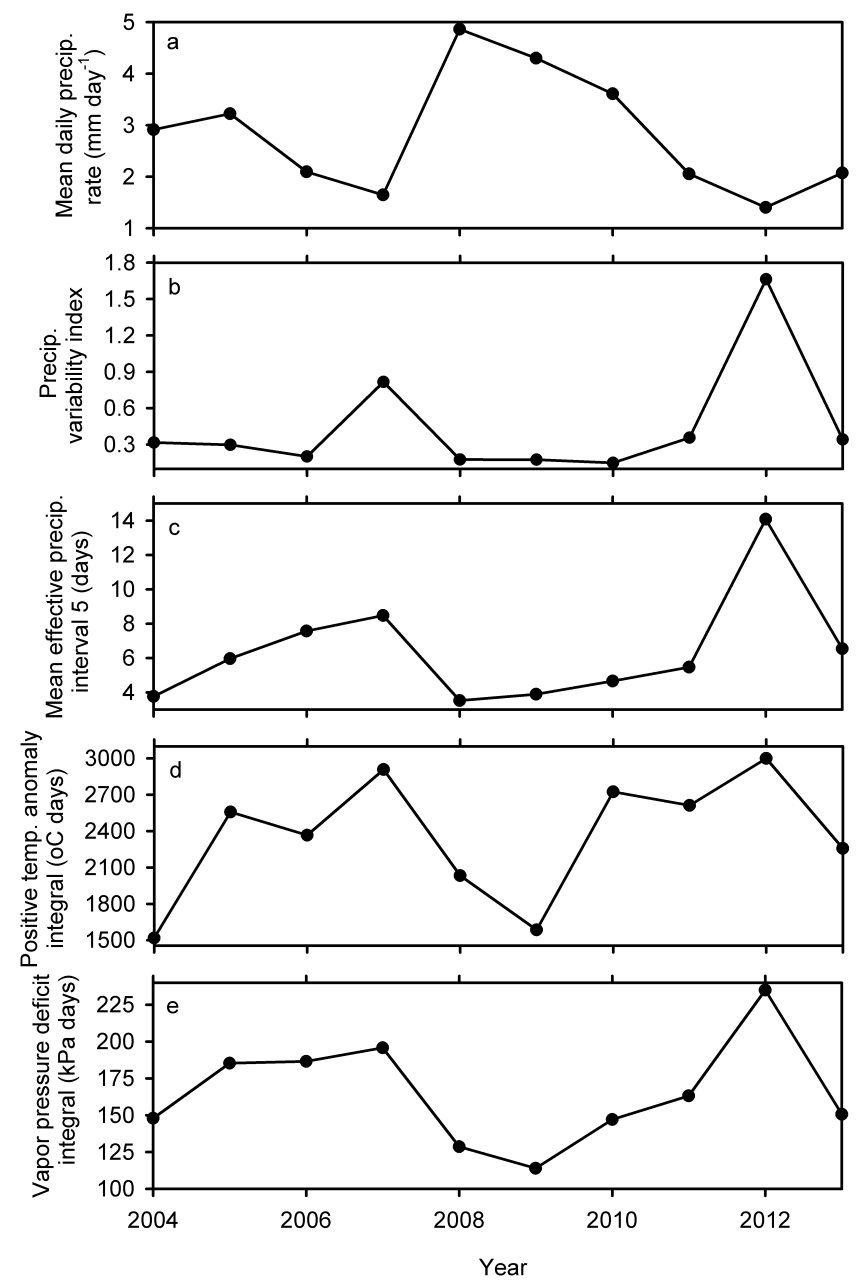

Figure 1. Inter-annual variations in the mean daily precipitation rate (a), precipitation variability index (b), mean effective precipitation interval with a threshold daily precipitation rate of $5 \mathrm{~mm} \mathrm{day}^{-1}$ (c), positive temperature anomaly integral (d) and vapor pressure deficit integral (e). Only growing-season data (days 120-300) are used in the calculation.

were not independent but were also not perfectly correlated either, suggesting that these potential predictors contain independent information at least to some degree that may be useful for relating to inter-annual variations in tree mortality.

\subsection{Seasonal, inter-annual and species variations in $\psi_{\text {pd }}$}

Large inter-annual variations in precipitation regimes led to contrasting seasonal patterns in $\psi_{\mathrm{pd}}$ for different years and for different species (Figs. 2, 3). For much of the growing seasons of the 2 driest years, 2012 (Fig. 3c) and 2007 (Fig. 2d), $\psi_{\text {pd }}$ of all species measured was consistently below the severe water stress threshold $(-1.5 \mathrm{MPa})$ suggested by Hsiao (1973). Because $\psi_{\text {pd }}$ generally marks the highest leaf water potential in the diurnal cycle, the maximal water stress that the plants at the MOFLUX site experienced during
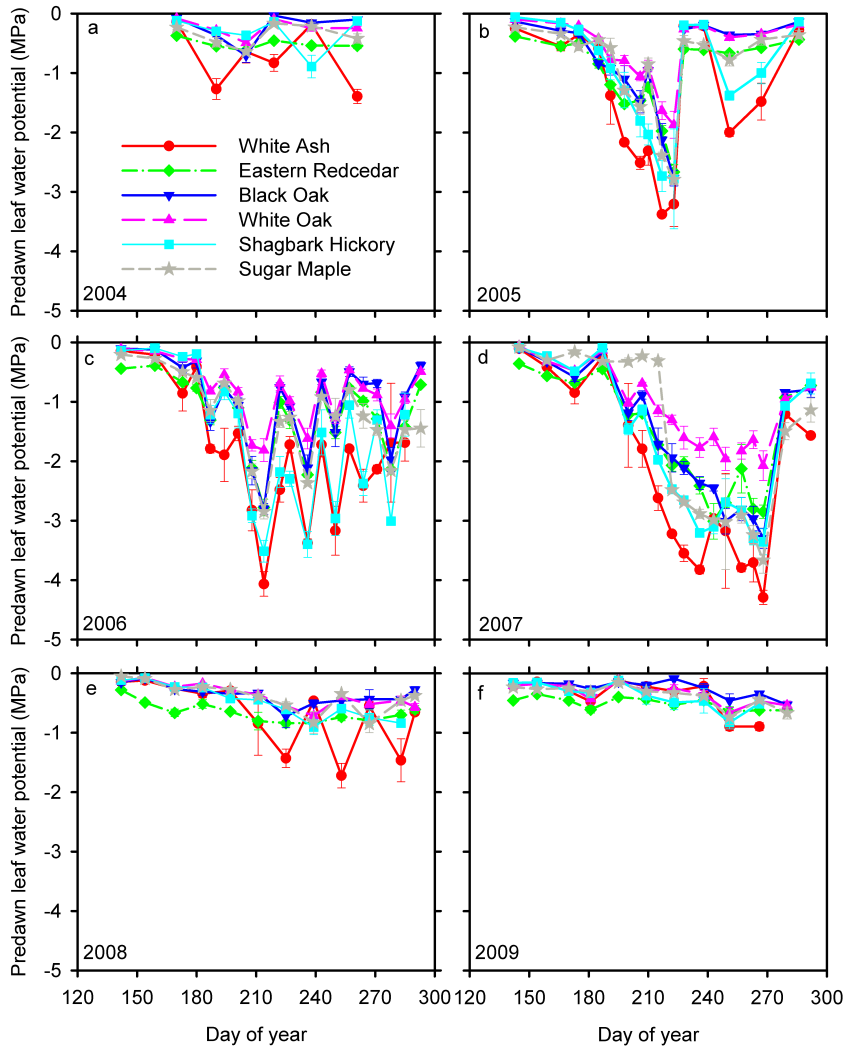

Figure 2. Seasonal variations in predawn leaf water potential of different species from 2004 to 2009.

the day (i.e., noon to early afternoon) were likely even more severe than indicated by $\psi_{\mathrm{pd}}$. If we use $-2.0 \mathrm{MPa}$ as a severe water stress threshold, nearly all species had $\psi_{\text {pd }}$ below this threshold at some point in 2005, 2006, 2007, 2011, 2012, and 2013. During the peak of the drought in 2012, $\psi_{\text {pd }}$ of all species approached or declined below -4 MPa while in 2007 the lowest value varied considerably across species, ranging from around $-2 \mathrm{MPa}$ (white oak) to below $-4 \mathrm{MPa}$ (white ash). In 2005 (Fig. 2b), $\psi_{\text {pd }}$ steadily decreased initially as the growing season progressed but the decreasing trend was interrupted by heavy mid-season rain which rehydrated the trees. In 2006, 2011 and 2013 (Figs. 2c, 3b, and c, respectively), repeated drying and rehydrating cycles caused fluctuations in $\psi_{\text {pd }}$. The years 2004, 2008, 2009 and 2010 were relatively wet and for the entire growing seasons of these years, no species had $\psi_{\text {pd }}$ below $-1 \mathrm{MPa}$ except for white ash. It is significant to note that the recovery of $\psi_{\mathrm{pd}}$ after soaking rains was prompt and complete, even during severe drought years (e.g., 2007, Fig. 2d; 2012, Fig. 3c).

Large differences in seasonal patterns of $\psi_{\text {pd }}$ existed among different species under the same precipitation regimes. White ash consistently had the lowest $\psi_{\text {pd }}$ among all species when the community in general had $\psi_{\text {pd }}$ below $-1 \mathrm{MPa}$. Above $-1 \mathrm{MPa}$, eastern redcedar tended to have the lowest $\psi_{\text {pd }}$. Therefore on short timescales ( $\sim$ a couple of 


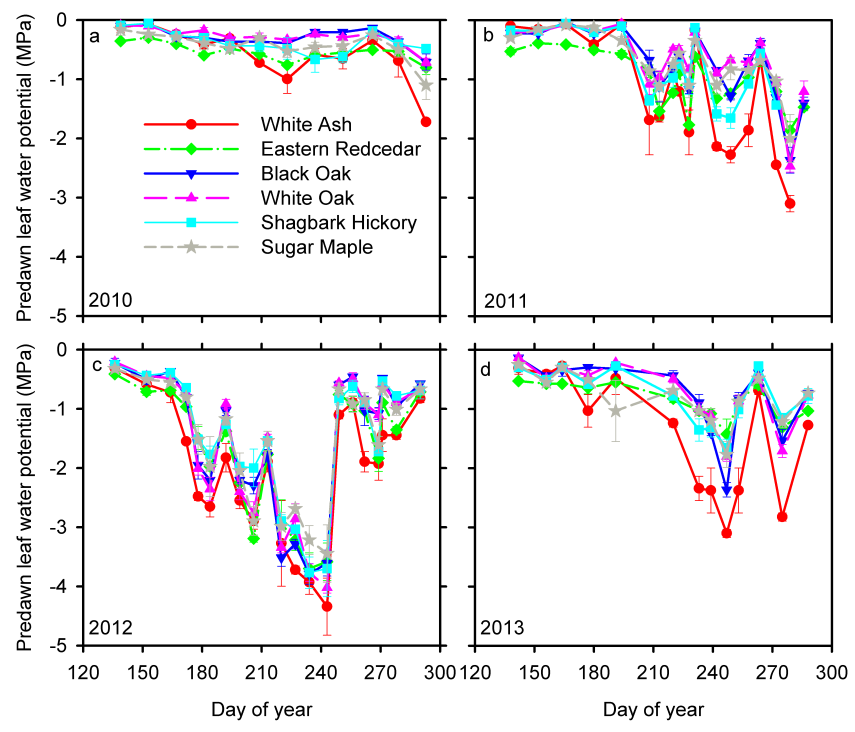

Figure 3. Seasonal variations in predawn leaf water potential of different species from 2010 to 2013.

weeks), the relative positions of different species in the crossspecies variations in $\psi_{\mathrm{pd}}$ were not fixed in time, depending on the level of water availability at a particular moment. When well hydrated, all species had similar $\psi_{\mathrm{pd}}$ except for eastern redcedar, whose $\psi_{\mathrm{pd}}$ slightly departed from those of other species (for example, Fig. 2e for the early growing season of 2008). Because white ash tended to have the lowest $\psi_{\text {pd }}$ under dry conditions but similar $\psi_{\text {pd }}$ as other species under wet conditions, the $\psi_{\mathrm{pd}}$ of white ash fluctuated more widely than other species both within and across the years, suggesting that it was the species least able to access deep soil water during drought. In contrast, white oak tended to have the highest (least negative) and least variable $\psi_{\text {pd }}$ among all species, suggesting that it was the species most capable of accessing deep soil water. However, this contrast is not a complete representation of the observed patterns because species' capacity in preserving $\psi_{\text {pd }}$ depended on the intensity of drought. This relativity can be most clearly seen by comparing the seasonal variations in white oak, and to some extent black oak, $\psi_{\mathrm{pd}}$ with those in other species. During most years, the oaks had $\psi_{\text {pd }}$ considerably higher than other species. However, during the driest year of 2012 , their $\psi_{\text {pd }}$ was within the variations of that of other species. In fact differences among all species were much diminished in 2012 compared with 2007.

Species differences in $\psi_{\text {pd }}$ were reflected and more clearly seen in the inter-annual variations of PLWPI (Fig. 4). White ash had the lowest PLWPI among all species for all years except for the relatively wet year of 2009 when eastern redcedar had lower PLWPI than white ash. White and black oaks tended to have higher PLWPI for most years. However, in the drought of 2007 black oak PLWPI was only slightly higher than other species exclusive of white ash, and in the exceptional drought of 2012 both white and black oaks' PLWPIs

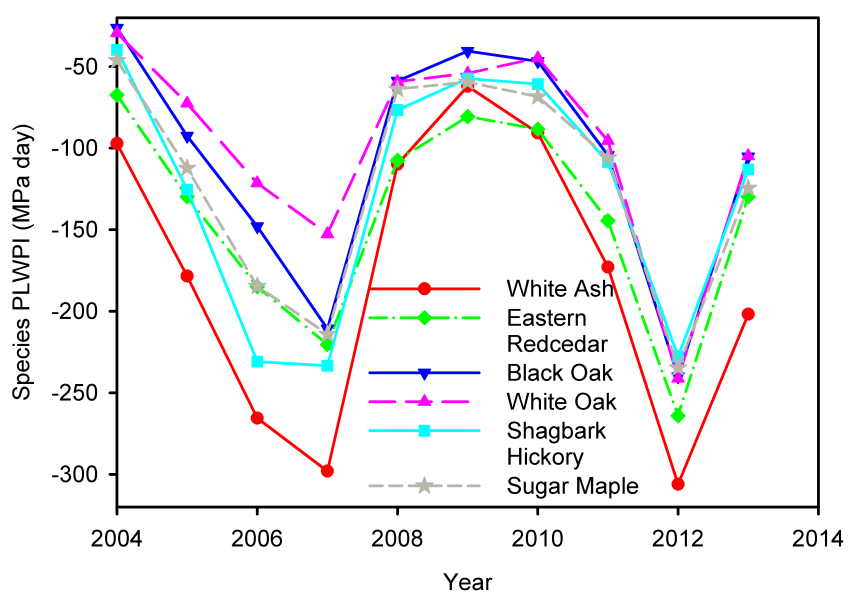

Figure 4. Inter-annual variations in PLWPI of different species from 2004 to 2013.

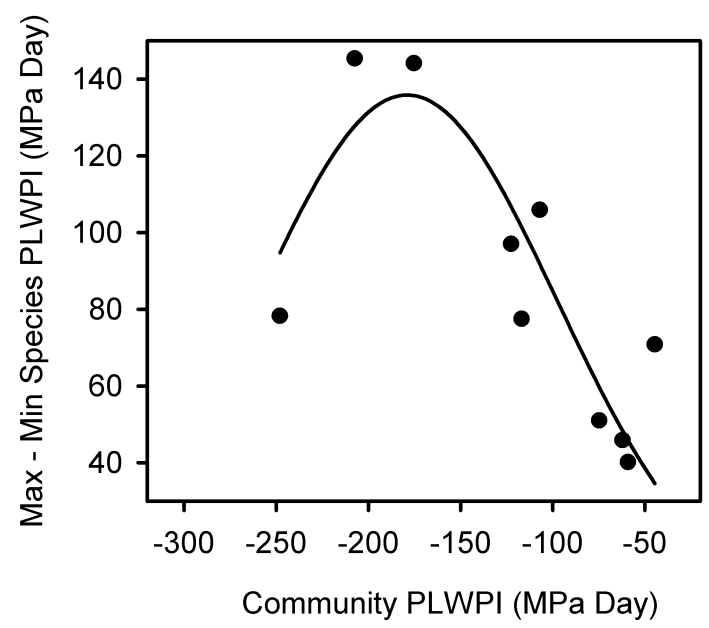

Figure 5. The difference between the maximum and minimum PLWPI among the six species studied as a function of the community PLWPI. The community PLWPI serves as a measure of overall water stress of a year. This figure shows that species differences in PLWPI reach the maximum at an intermediate level of water stress.

were only slightly higher than other species. As expected from the seasonal patterns in $\psi_{\mathrm{pd}}$ among species across years, the maximal difference in PLWPI among species $(\max -\min$ species PLWPI in each year) reached a maximum at an intermediate value of community PLWPI (Fig. 5), suggesting that the differences in $\psi_{\text {pd }}$ and PLWPI among species reached maximum when the site was under some intermediate levels of water stress and diminished towards either extreme wet or extreme dry conditions. Significantly, during the exceptional drought year of 2012 the superior capacity to keep PLWPI elevated was lost in both oak species. 


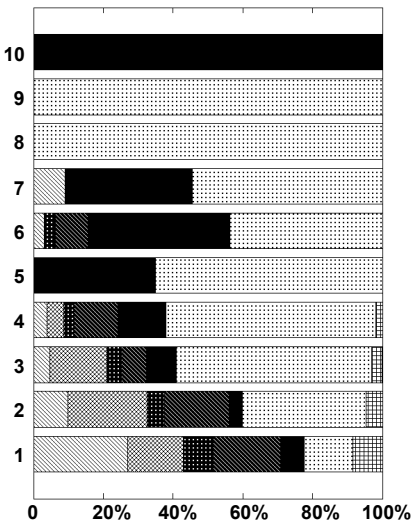

b

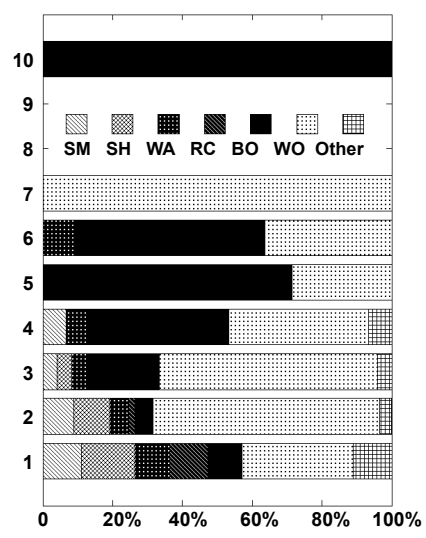

Figure 6. The relative abundance according to the 2005 forest inventory (a) and the total relative mortality of each species from 2005 to 2014 (b) in each diameter at breast height (DBH at $1.3 \mathrm{~m}$ ) class. The relative abundance is expressed as a percentage of stem number of each species relative to the total stand stem number in each DBH class. Similarly, the relative mortality is expressed as a percentage of total mortality of each species relative to the total stand mortality in each DBH class. Ten DBH classes with an equal width of $6.3 \mathrm{~cm}$ are shown. The class with the smallest DBH (class 1) starts with a DBH of $9 \mathrm{~cm}$. This figure shows whether members of a species die proportionally or disproportionally to its abundance in the stand. SM, sugar maple; SH, shagbark hickory; WA, white ash; $\mathrm{RC}$, eastern redcedar; $\mathrm{BO}$, black oak; WO, white oak; Other, the other species together.

\subsection{Variations of tree mortality with species, DBH classes and year}

At the MOFLUX site, white oak and black oak dominated the largest DBH classes of the stand while the abundance of other species increased in smaller DBH classes (Fig. 6a). Over the whole mortality monitoring period (2005-2014), the total mortality rate of a species as a percentage relative to the stand mortality in each DBH class (Fig. 6b) differed from this species' abundance in this given DBH class for most DBH classes and for most species (i.e., compare the bar lengths indicating relative abundance in Fig. 6a with the bar lengths indicating relative mortality in Fig. $6 \mathrm{~b}$ for the corresponding DBH classes). For example, in DBH classes 1-6 (DBH from 9 to $47 \mathrm{~cm}$ ), black oak had a mortality rate relative to the stand consistently higher than its relative abundance in the corresponding stand DBH classes as shown in the forest inventory data, indicating that black oaks died at a disproportionately higher rate within these DBH classes. In contrast, eastern redcedar and shagbark hickory had relative mortality rates lower than their relative abundances in each DBH class, suggesting that these two species had better survivability compared with other species.

The total mortality of the 2005-2014 period shown in Fig. $6 \mathrm{~b}$ was dominated by exceptionally high mortality in 2013 for most species, 1 year after the driest year of 2012 .
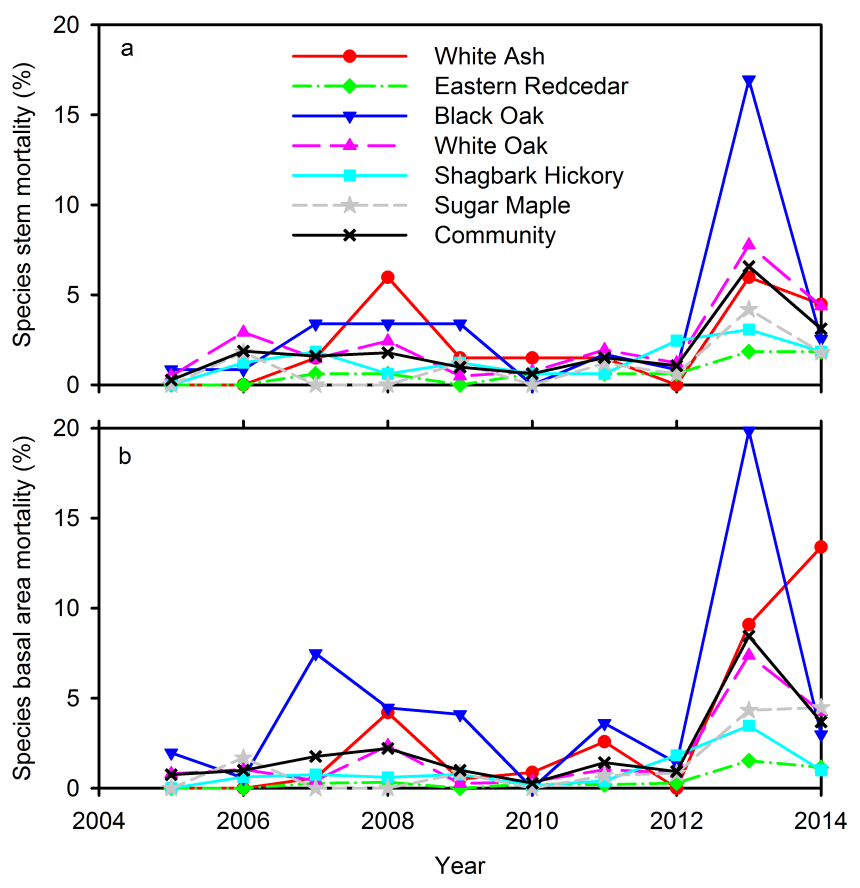

Figure 7. Inter-annual variations in the species mortality expressed relative to either the stem number density (a) or the basal area (b) of a species in 2005 .

Figure 7 showed the inter-annual variations of the yearly mortality rate expressed relative to species abundance in 2005, based on either stem number density (Fig. 7a) or basal area (Fig. 7b). For all species, the highest stem mortality occurred in 2013. This is also true for the basal area mortality; the only exception was white ash which had slightly higher basal area mortality in 2014 than in 2013, largely due to one very large tree that died in 2014. Considering that 2013 was a year with only modest water stress (Fig. 4), the mortality in 2014, 2 years after the driest year of 2012, appeared to be unusually high for most species and also for the community as a whole.

\subsection{Variations of tree mortality with potential predictors with time lag}

We analyzed how mortality changed with $\bar{p}$, PVI, MEPI5, PLWPI, PTAI, and VPDI for each species as well as for the community at different lag years $(0,1,2$ and 3 years there were not enough data to test for more lag years). We found that the relationships were strongest at 1 -year lag in all cases; i.e., the mortality in 1 year was best explained in terms of variance $\left(R^{2}\right)$ by the $\bar{p}$, PVI, MEPI5, PLWPI, PTAI and VPDI in the previous year (all fittings in this case were linear with the same number (i.e. Eq. 2) of parameters, making $R^{2}$ comparable). This 1 -year lag can be already expected from the fact that the highest mortality occurred in 2013, 1 year after the driest year of 2012. Both at the species and 

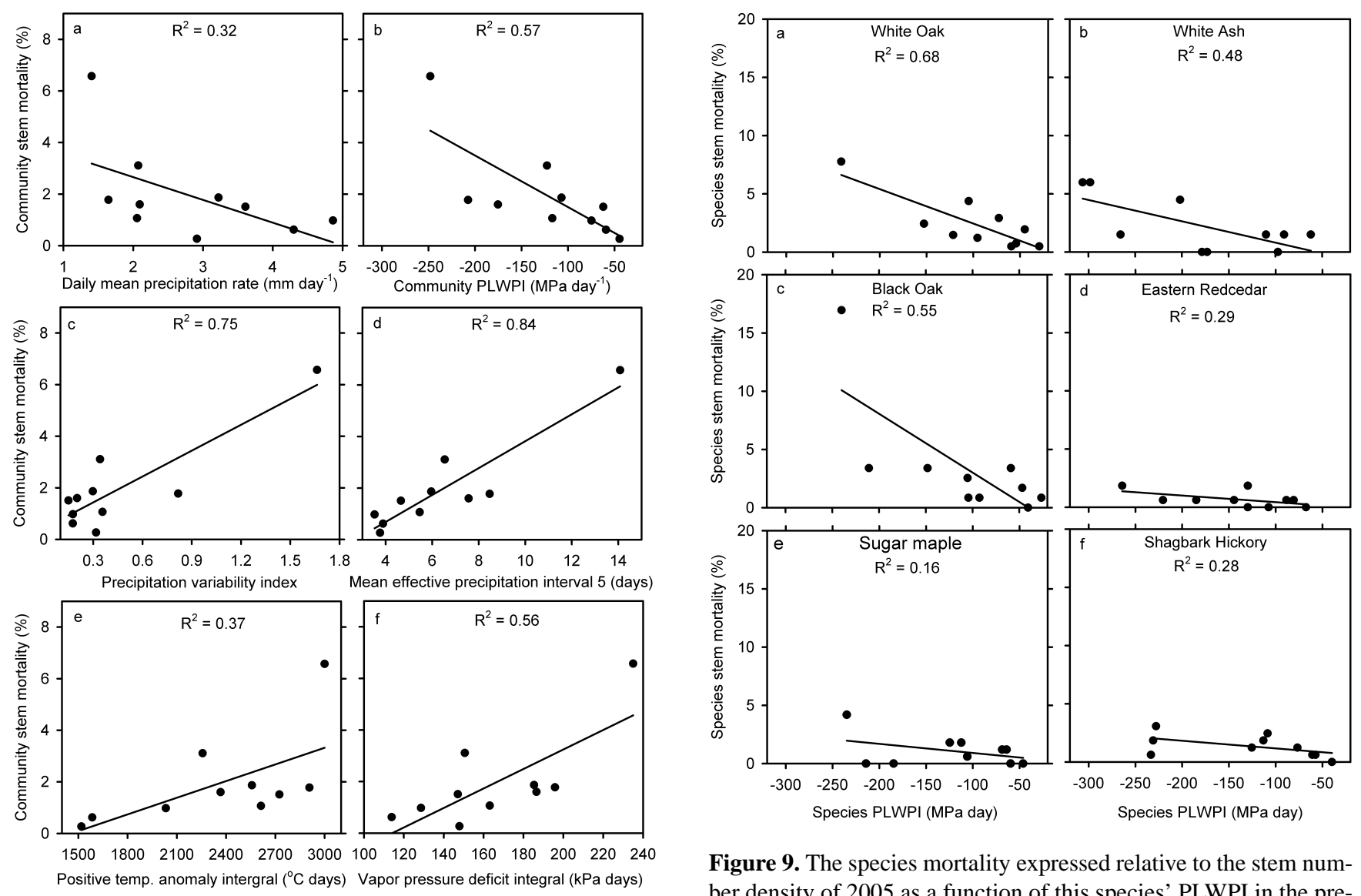

Figure 9. The species mortality expressed relative to the stem number density of 2005 as a function of this species' PLWPI in the previous year. Fittings are linear.

Figure 8. The mortality of the plant community as a whole expressed relative to the stem number density of 2005 as a function of the previous year's daily mean precipitation rate (a), PLWPI at the community level (b), precipitation variability index (c), mean effective precipitation interval with a threshold daily precipitation rate of $5 \mathrm{~mm} \mathrm{day}^{-1}$ (d), positive temperature anomaly integral (e), and vapor pressure deficit integral (f). Fittings are linear.

community levels, stem mortality rates decreased with an increase in the previous year's $\bar{p}$ (Figs. $8 \mathrm{a}, \mathrm{S} 1$ in Supplement) and PLWPI (Figs. 8b, 9) and increased with an increase in the previous year's PVI (Figs. 8c, S2), MEPI5 (Figs. 8d, 10), PTAI (Figs. 8e, S3) and VPDI (Figs. 8f, S4). Based on the explained variance, the most promising predictors of tree mortality were PLWPI and MEPI5 while the performance of PVI, PTAI and VPDI was also reasonable. The predictive capacity of $\bar{p}$ was limited because it did not contain precipitation variability information. The results from the analyses with the basal area mortality rates showed similar patterns and therefore are not presented here.

Although we found that the relationships between mortality and predictors appear to be strongest with a 1-year lag, this does not imply droughts do not have longer-term impacts. For example, the unusually high mortality of tree species in 2014 (Fig. 7) may be a result of lingering impact of the exceptional drought of 2012 as the 2013 drought was not

strong (Figs. 2-4). When the previous 2 year's MEPI5s were used to form a composite MEPI5 in year $t[=\operatorname{MEPI5}(t-$ $1)+0.5 \times \operatorname{MEPI} 5(t-2)]$, the composite MEPI5 explained more variance in tree mortality than the previous year's MEPI5 alone (Fig. S5). The better performance of the composite MEPI5 suggests a drought can affect tree mortality 2 years later.

The variations of mortality rates with the previous year's $\bar{p}$, PVI, MEPI5, PLWPI, PTAI and VPDI were clearly dominated by the impact of the exceptional drought of 2012 . However, the impact of 2012 was not the sole determinant of the relationships. When the mortality data for 2013 and 2014 were excluded from the analysis, a linear regression still explained much of the variance in the inter-annual variations of mortality (Fig. S6). In fact, PTAI (Fig. S6e) and VPDI (Fig. S6f) even explained higher variances when the "outliers" were removed, suggesting that these two predictors may work well for moderate drought. 

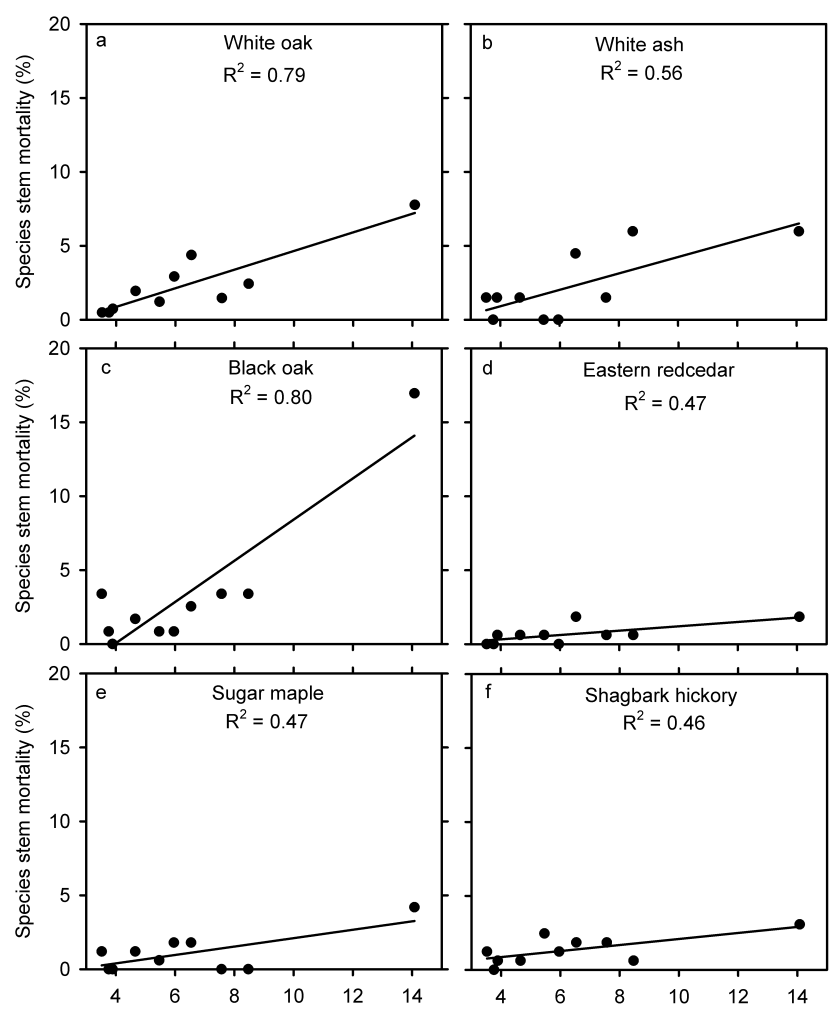

Mean effective precipitation interval 5 (days) Mean effective precipitation interval 5 (days)

Figure 10. The species mortality expressed relative to the stem number density of 2005 as a function of the mean effective precipitation integral with a threshold daily precipitation rate of $5 \mathrm{~mm} \mathrm{day}^{-1}$ (MEPI5) in the previous year. Fittings are linear.

\subsection{Mortality and drought tolerance of tree species}

Within the same species, mortality decreased with an increase (i.e., becoming less negative) in the previous year's PLWPI. However, the mortality-PLWPI relation across species is more complicated and is not monotonic. For example, the drought-tolerant white and black oaks generally had higher (less negative) PLWPI than the less drought-tolerant sugar maple and shagbark hickory, and the drought-tolerant eastern redcedar (Fig. 4), but their mortality was also higher than the latter three species, especially after the most severe drought year of 2012 (Fig. 7). In contrast, the less droughttolerant white ash exhibited lower PLWPI (Fig. 4) but higher mortality than sugar maple, shagbark hickory, and eastern redcedar (Fig. 7). These differences across species can also be inferred from plots of annual mortality as a function of the previous year's PLWPI (Fig. 9).

A more clear demonstration of how the mortality of a species is related to its general capacity in regulating $\psi_{\mathrm{pd}}$ and PLWPI is given by Fig. 11. Because the mortality sampling population for any particular year was relatively small for species with less abundance in the community (e.g., white ash and shagbark hickory; Fig. 6a), in Fig. 11 we pooled the
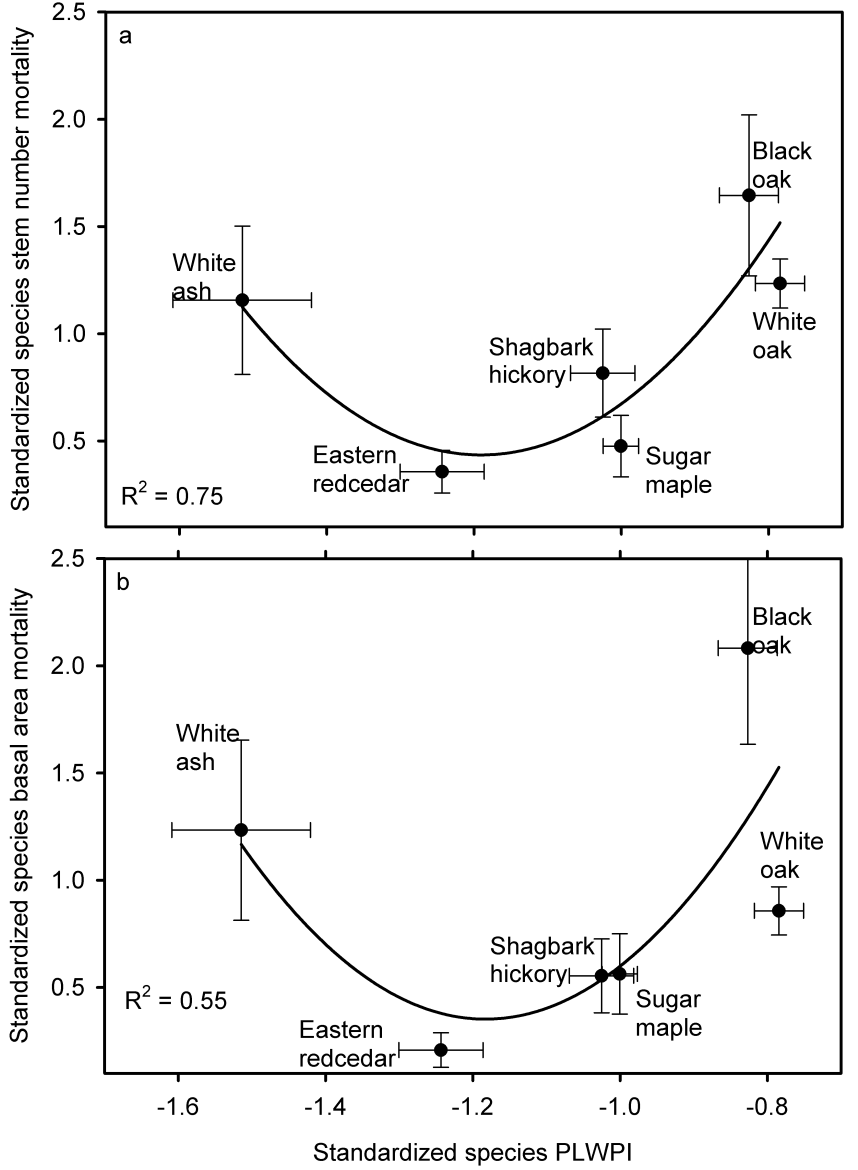

Figure 11. The mean standardized species mortality as a function of the mean standardized PLWPI. In each year and for each species, the standardization is done by dividing a species mortality by the community mortality or by dividing a species PLWPI by the absolute value of the community PLWPI. The standardized yearly values are then averaged across the years. The standardization preserves the relative positions of species in the PLWPI continuum. Mortality is either expressed based on stem number density (a) or basal area (b). This figure shows that species occupying middle positions along the relative PLWPI continuum suffered less mortality than those at either extremes (i.e., extremely high or low relative PLWPI).

decade-long data to focus on the mortality difference among species. The pooling also allowed us to compare species in their general capacity to regulate the dynamics of $\psi_{\mathrm{pd}}$ and to determine how this capacity may be related to the risk of drought-influenced mortality. The PLWPI of a species in a year was normalized by the absolute value of the community PLWPI of this year and then averaged across the 10-year period. Because the PLWPI of all species was divided by the same value in a given year, this standardization procedure preserved their relative positions along the PLWPI continuum and yet allowed different years of widely varying water stress levels to be averaged. Similarly, the annual mortality of a species in a year was normalized by the community mortal- 
ity of this year and then averaged across the 10-year period. With these normalizations, a clear convex pattern emerged (Fig. 11): species occupying the middle of the standardized PLWPI continuum (eastern redcedar, shagbark hickory and sugar maple) suffered less mortality than those in the low standardized PLWPI end (white and black oaks) or in the high standardized PLWPI end of the continuum (white ash).

\section{Discussion}

A wide range of precipitation regimes from ample seasonal moisture to exceptional drought was observed over the 10year tree mortality study period at the MOFLUX site, as reflected in both precipitation variables and PLWPI. The generally tight correlation between precipitation regimes and time-delayed (1 year or more) inter-annual variations in the mortality of tree species strongly supports the assertion that drought was an important factor in death of trees during the study. Although different species had variable degrees of water stress and drought tolerance, the mortality of all species increased after the exceptional drought of 2012. These results are consistent with worldwide syntheses of droughtrelated mortality reports (e.g., Breshears et al., 2009; Allen et al., 2010). Furthermore, the close relationships of mortality with various predictors, especially PLWPI, MEPI5, PTAI and VPDI, even without considering the exceptional drought year of 2012, indicate the apparent importance of non-extreme plant water stress in promoting mortality (cf. Breshears et al., 2009).

Non-extreme water stress is also important for understanding species' differences in regulating their internal water environment. Under very wet conditions, all species are hydrated equally well while under extreme drought conditions, any capacity of species in maintaining $\psi_{\mathrm{pd}}$ and PLWPI may be overwhelmed by a lack of water even in deep soil. Only under intermediate drought levels can any regulatory mechanism that a species might have function effectively (Fig. 5). Thus, non-extreme water stress may be the optimal condition for revealing differences in plant water relations across different species.

Because we did not measure hydraulic conductivity in our species, we cannot assert that xylem cavitation did not occur during any of the drought events. However, two lines of evidence indicated there was no catastrophic loss of xylem hydraulic conductivity in any species. First, mortality lagged PLWPI by a year without the evidence of nearly immediate shoot desiccation that would follow catastrophic hydraulic disconnection. There was some leaf scorching at the top of the canopy during 2012, associated with the exceptional drought and high temperatures (e.g., during July $\psi_{\text {pd }}$ fell below $-3 \mathrm{MPa}$ and average temperature was $5^{\circ} \mathrm{C}$ above the 1980-2010 average), but no signs of leaf desiccation (leaf curling, cracking or green hue change in laminae). Second, during all drought events including the exceptional drought of 2012, $\psi_{\text {pd }}$ recovered rapidly after wetting rains. This type of response would not be expected if catastrophic hydraulic disconnection had occurred; rather, one would have expected little or no recovery in $\psi_{\text {pd }}$. One could argue that xylem refilling and consequent recovery of conductivity might occur with rainfall, but such refilling would have had to be initiated when xylem water potentials were below (and sometimes far below) those considered conducive to xylem refilling (e.g., Secchi and Zwieniecki, 2010; Brodersen and McElrone, 2013; Rockwell et al., 2014). Further, as noted above, the concept of rapid refilling in xylem under significant tensions itself is being reconsidered in the light of recent research suggesting that conventional techniques of measuring hydraulic conductivity overestimate xylem cavitation and increasingly so as tensions increase (e.g., Wheeler et al., 2013; Cochard and Delzon, 2013; Rockwell et al., 2014; Cochard et al., 2015). Hence, drought-related mortality in this forest likely cannot be directly linked to hydraulic disconnection. Rather, a significant but less direct role for drought as one determinant of mortality seems more likely (McDowell et al., 2013b).

Species exhibited differences in the static component of water stress represented by $\psi_{\text {pd }}$, notably with white ash having generally lower values than other species. However, with ample rain and thus abundant soil moisture, eastern redcedar had lower $\psi_{\text {pd }}$. This last response has been observed before (Ginter-Whitehouse et al., 1982; Bahari et al., 1985) and likely relates to the higher-resistance tracheid anatomy of redcedar which prevents full overnight equilibration in moist soil. Comparative analysis of water relations among species, while not arbitrary, must necessarily be limited to the species studied. In a broader context of previous studies in this forest, it is worth noting that another fairly common tree species at the site (viz., black walnut (Juglans nigra L.)) exhibits even higher $\psi_{\text {pd }}$ than the oak species studied here, and that white ash (heretofore not studied extensively in this forest) exhibited responses similar to flowering dogwood (Cornus florida L.) (Bahari et al., 1985; Ni and Pallardy, 1991; Loewenstein and Pallardy, 1998). It must be emphasized that none of these species showed any indication of hydraulic disconnection, as determined by failure in recovery of $\psi_{\text {pd }}$ after significant rainfall (e.g., Bahari et al., 1985; Lowenstein and Pallardy, 1998). Thus, these results also suggest the established link between PLWPI and mortality must be mediated indirectly.

PLWPI was a monotonic predictor of drought-influenced tree mortality within a species and for the plant community as a whole; i.e., the lower it was, the higher was the subsequent year's mortality. However, the PLWPI-mortality relationship varied substantially across species. Our data indicated that species with extreme (lowest or highest) positions in the continuum of PLWPI suffered higher mortality than species with intermediate values of PLWPI. The relationships among PLWPI, mortality and species-relative drought tolerance also were complex. Whereas drought-tolerant oak species had both higher PLWPI (indicating greater relative capacity to 
avoid low $\psi_{\mathrm{pd}}$ ) and higher mortality, eastern redcedar had lower PLWPI and mortality. Similarly, while the relatively less drought-tolerant white ash had the lowest PLWPI (indicating low capacity to avoid low $\psi_{\text {pd }}$ ) and high mortality, sugar maple and shagbark hickory had higher PLWPI and lower mortality. Thus, white ash's native capacity to tolerate drought may have been exceeded during the study period, and particularly so during the 2012 drought. Elevation of oak species mortality likely has a complex explanation. The exceptional drought of 2012 did nearly eliminate the differential capacity of the oak species to maintain high $\psi_{\mathrm{pd}}$, thus inducing atypically high levels of water stress. While these oak species are more important at sites with lower soil water supply capacity and demonstrate drought-tolerant physiological attributes (e.g., Fralish et al., 1978; Abrams, 1990, 2003), they become more susceptible to drought, and drought-related mortality, as they age (e.g., Jenkins and Pallardy, 1995; McCarthy et al., 2001; Voelker et al., 2008). Consistent with this assertion, relative mortality of oaks in the present study was concentrated in the larger (older) size classes (Fig. 6). Furthermore, as also was observed here, previous research has shown that red oak group species such as black oak show greater rates of mortality in drought-related mortality events than members of the white oak group (e.g., Fan et al., 2006, 2008; Greenberg et al., 2011).

Unless being killed outright, a tree's life terminates when sufficient resources are either not available (Waring, 1987) or come too late to revive vital coordinated organ activities. This death process is an end-point response that integrates past internal and external dynamics (Hanson et al., 2003) and is thus hard to predict mechanistically. However, tree mortality is unique as a life-ending process due to two fundamental characteristics of a tree's life. First, trees are sessile and thus have very limited capacity to evade environmental stresses. Second, trees can be potentially immortal due to their integrated biology of modular structure and meristem dormancy, therefore, some external agent must occur to induce their death. The combination of these two characteristics means that while it is difficult to mechanistically predict tree mortality, the possibility exists to make robust empirical predictions if sufficiently long, concerted observations are made on both tree mortality and responsible external agents.

Our study demonstrates that this strategy can be particularly fruitful for predicting drought-influenced tree mortality. PLWPI and MEPI in the growing season of the prior year are good predictors of tree mortality in the current year. The mean precipitation rate does not contain information about precipitation variability while PVI lacks information about precipitation amount. Thus, individually, they are not as good as PLWPI or MEPI in predicting tree mortality except for mortality caused by severe droughts; they must be used jointly to serve as predictors of tree mortality. PTAI and VPDI apparently work better for non-extreme droughtinfluenced tree mortality but may have limited capacity for a broad range of water stress including extreme drought. Obvi- ously these predictors will need to be tested at multiple sites and with longer data sets before any conclusion can be drawn with respect to which predictor(s) is the best for predicting drought-influenced tree mortality.

\section{Conclusions}

Our study has revealed that the drought-influenced mortality of tree species varies nonlinearly along physiologically based and meteorological drought intensity scales, and such variations can be predicted by multiple, simply constructed indices with a 1-year time lag. These indices include predawn leaf water potential integral (PLWPI), mean effective precipitation interval (MEPI), precipitation variability index (PVI), positive temperature anomaly integral (PTAI), and vapor pressure deficit integral (VPDI). While hydraulic disconnection in the xylem has been postulated as a mechanism for drought-influenced tree mortality, significant but indirect effects of drought are more likely the main cause of tree death in our study. Less severe droughts can not only be significant promotors of tree death but also reveal species differences in drought-tolerance capacity that might be related to mortality risk. While species may possess different mechanisms to regulate their internal hydraulic environment, such mechanisms can only work under the limits imposed by the external environment; beyond these limits, species differences in the effectiveness of regulatory mechanisms become minimal. Severe droughts may overwhelm the capacity of even drought-tolerant species to maintain differential levels of water potential as the soil becomes exhausted of available water in the rooting zone, thus rendering them more susceptible to die if predisposed by other factors such as age. Our study also showed that the drought-influenced tree mortality is related to the species position along the spectrum of predawn leaf water potential with those in either ends of the spectrum being associated with elevated risk.

Forest composition at the MOFLUX site is undergoing change today. The disproportionally high mortality of black and white oaks and white ash in the present study suggest that frequent droughts may cause the forest to transition to a plant community that is composed of species occupying intermediate positions in the continuum of predawn leaf water potential regulation capacity. This finding may have implications for the future of forest ecosystems in the eastern US.

Although reports of tree mortality caused by episodic drought events have been extensive in the literature, studies based on long-term, continuous observations such as represented by this present study have been rare (e.g., Breshears et al., 2009). Yet, understanding tree mortality mechanisms and developing predictive models of tree mortality require long-term continuous monitoring of tree mortality and environmental factors. Tree mortality caused by episodic drought events must be investigated in the long-term background of mortality and environmental dynamics. There is a need for 
increased investment on coordinated long-term observations of tree mortality and responsible external forcing agents in global forests.

\section{The Supplement related to this article is available online at doi:10.5194/bg-12-2831-2015-supplement.}

Acknowledgements. We thank Renee Marchin, Trevor Keenan, Jason Hubbart and two anonymous referees for critical comments and constructive suggestions. This material is based upon work supported by the US Department of Energy, Office of Science, Office of Biological and Environmental Research Program, Climate and Environmental Sciences Division. ORNL is managed by UT-Battelle, LLC, for the US Department of Energy under contract DE-AC0500OR22725. US Department of Energy support for the University of Missouri (grant DE-FG02-03ER63683) is gratefully acknowledged.

This paper has been authored by UT-Battelle, LLC, under contract no. DE-AC05-00OR22725 with the US Department of Energy. The United States Government retains and the publisher, by accepting the article for publication, acknowledges that the United States Government retains a non-exclusive, paid-up, irrevocable, worldwide license to publish or reproduce the published form of this manuscript, or allow others to do so, for United States Government purposes.

Edited by: T. Keenan

\section{References}

Abrams, M. D.: Adaptations and responses to drought in Quercus species of North America, Tree Physiol., 7, 227-238, 1990.

Abrams, M. D.: Where has all the white oak gone?, Bioscience, 53, 927-939, 2003.

Adams, H. D., Guardiola-Claramontea, M., Barron-Gafford, G. A., Villegas, J. C., Breshears, D. D., Zou, C. B., Troch, P. A., and Huxman, T. E.: Temperature sensitivity of drought-induced tree mortality portends increased regional die-off under globalchange-type drought, Proc. Natl. Acad. Sci. USA, 106, 70637066, 2009.

Allen, C. D., Macalady, A. K., Chenchouni, H., Bachelet, D., Mcdowell, N., Vennetier, M., Kitzberger, T., Rigling, A., Breshears, D. D., Hogg, E. H., Gonzalez, P., Fensham, R., Zhang, Z., Castro, J., Demidova, N., Lim, J. H., Allard, G., Running, S. W., Semerci, A., and Cobb, N.: A global overview of drought and heatinduced tree mortality reveals emerging climate change risks for forests, Forest Ecol. Manage., 259, 660-684, 2010.

Anderegg, L. D. L., Anderegg, W. R. L., Abatzoglou, J., Hausladen, A. M., and Berry, J. A.: Drought characteristics' role in widespread aspen forest mortality across Colorado, USA, Glob. Change Biol., 19, 1526-1537, 2013.

Anderegg, W. R. L., Anderegg, L. D. L., Berry, J. A., and Field, C. B.: Loss of whole-tree hydraulic conductance during severe drought and multi-year forest die-off, Oecologia, 175, 11-23, 2014.
Anderson, D. R.: Modeled Based Inference in the Life Sciences: A Primer on Evidence, Springer, New Yorker, 184 pp., 2010.

Bahari, Z. A., Pallardy, S. G., and Parker, W. C.: Photosynthesis, water relations and drought adaptation in six woody species of oak-hickory forests in central Missouri, For. Sci., 31, 557-569, 1985.

Belden, A. C. and Pallardy, S. G.: Successional trends and apparent Acer saccharum regeneration failure in an oakhickory forest in central Missouri, USA, Plant Ecol., 204, 305-322, 2009.

Blum, A.: Drought resistance - is it really a complex trait?, Funct. Plant Biol., 38, 753-757, 2011.

Breshears, D. D., Myers, O. B., Meyer, C. W., Barnes, F. J., Zou, C. B., Allen, C. D., Mcdowell, N. G., and Pockman, W. T.: Research communications research communications tree die-off in response to global change-type drought: Mortality insights from a decade of plant water potential measurements, Front. Ecol. Environ., 7, 185-189, 2009.

Brodersen, C. R. and McElrone, A. J.: Maintenance of xylem network transport capacity: A review of embolism repair in vascular plants, Front. Plant Sci., 4, 1-11, 2013.

Cochard, H. and Delzon, S.: Hydraulic failure and repair are not routine in trees, Ann. Forest Sci., 70, 659-661, 2013.

Cochard, H., Delzon, S., and Badel, E.: X-ray microtomography (micro-CT): A reference technology for high-resolution quantification of xylem embolism in trees, Plant, Cell Environ., 38, 201-206, 2015.

Cook, B. I., Ault, T. R., and Smerdon, J. E.: Unprecedented 21st century drought risk in the American Southwest and Central Plains, Sci. Adv., 1, doi:10.1126/sciadv.1400082, 2015.

Critchfield, H. J.: General Climatology, Prentice-Hall, Upper Saddle River, N. J., 1966.

Eamus, D., Boulain, N., Cleverly, J., and Breshears, D. D.: Global change-type drought-induced tree mortality: vapor pressure deficit is more important than temperature per se in causing decline in tree health, Ecol. Evolut., 3, 2711-2729, 2013.

Fan, Z., Kabrick, J. M., and Shifley, S. R.: Classification and regression tree based survival analysis in oak-dominated forests of Missouri's Ozark highlands, Can. J. Forest Res., 36, 1740-1748, 2006.

Fan, Z., Kabrick, J. M., Spetich, M. A., Shifley, S. R., and Jensen, R. G.: Oak mortality associated with crown dieback and oak borer attack in the Ozark Highlands, Forest Ecol. Manage., 255, 2297 2305, 2008.

Fralish, J. S., Jones, S. M., O’Dell, R. K., and Chambers, J. L.: The effect of soil moisture on site productivity and forest composition in the Shawnee Hills of southern Illinois. (ed Balmer, WE) Proceedings: Soil Moisture-site Productivity Symposium, Southeastern Area, State and Private Forestry, USDA Forest Service, 263-285, 1978.

Ginter-Whitehouse, D. L., Hinckley, T. M., and Pallardy, S. G.: Spatial and temporal aspects of water relations of three tree species with different vascular anatomy, For. Sci., 29, 317-29, 1983.

Greenberg, C. H., Keyser, T. L., and Speer, J. H.: Temporal patterns of oak mortality in a southern Appalachian forest (1991-2006), Nat. Areas J., 31, 131-137, 2011.

Gu, L., Meyers, T., Pallardy, S. G., Hanson, P. J., Yang, B., Heuer, M., Hosman, K. P., Riggs, J. S., Sluss, D., and Wullschleger, S. D.: Direct and indirect effects of atmospheric conditions and soil moisture on surface energy partitioning revealed by a prolonged 
drought at a temperate forest site, J. Geophys. Res.-Atmos., 111, D16102, doi:10.1029/2006JD007161, 2006.

Gu, L., Meyers, T., Pallardy, S. G., Hanson, P. J., Yang, B., Heuer, M., Hosman, K. P. , Liu, Q., Riggs, J. S., Sluss, D., and Wullschleger, S. D.: Influences of biomass heat and biochemical energy storages on the land surface fluxes and radiative temperature, J. Geophys. Res.-Atmos., 112, D02107, doi:10.1029/2006JD007425, 2007.

Gu, L., Pallardy, S. G., Tu, K., Law, B. E., and Wullschleger, S. D.: Reliable estimation of biochemical parameters from $\mathrm{C}_{3}$ leaf photosynthesis-intercellular carbon dioxide response curves, Plant Cell Environ., 33, 1852-1874, 2010.

Hacke, U. G., Stiller, V., Sperry, J. S., Pittermann, J., and Mcculloh, K. A.: Cavitation fatigue. Embolism and refilling cycles can weaken the cavitation resistance of xylem, Plant Physiol., 125, 779-786, 2001.

Hanson, P. J., Todd, D. E., and Huston, M. A.: Walker Branch throughfall displacement experiment (TDE), in: North American Temperate Deciduous Forest Responses to Changing Precipitation Regimes, edited by: Hanson, P. J. and Wullschleger, S. D., Ecological Studies 166, Springer, New York, 8-31, 2003.

Hinckley, T. M., Tesky, R. O., Duhme, F., and Richter, H.: Temperate hardwood forests, in: Water deficits and plant growth IV: Woody plant communities, edited by: Kozlowski, T. T., Academic, New York, 154-197, 1981.

Hoffmann, W. A., Marchin, R. M., Abit, P., and Lau, O. L.: Hydraulic failure and tree dieback are associated with high wood density in a temperate forest under extreme drought, Glob. Change Biol., 17, 2731-2742, 2011.

Hsiao, T. C.: Plant responses to water stress, Annu. Rev. Plant Physiol., 24, 519-570, 1973.

Jenkins, M. and Pallardy, S. G.: The influence of drought on red oak group species growth and mortality in the Missouri Ozarks, Can. J. Forest Res., 25, 1119-1127, 1995.

Kozlowski, T. T. and Pallardy, S. G.: Acclimation and adaptive responses of woody plants to environmental stresses, Botan. Rev., 68, 270-334, 2002.

Kubiske, M. E. and Abrams, M. D.: Ecophysiological analysis of woody species in contrasting temperate communities during wet and dry years, Oecologia, 98, 303-312, 1994.

Ludlow, M. M.: Strategies of response to water stress, in: Structural and functional responses to environmental stress: water shortage, edited by: Kreeb, K. H., Richter, H., and Hinckley, T. M., SPB Academic Publishing, Amsterdam, Netherlands, 269-81, 1989.

Loewenstein, N. J. and Pallardy, S. G.: Drought tolerance, xylem sap abscisic acid and stomatal conductance du Amsterdam, Netherlandsring soil drying: A comparison of canopy trees of three temperate deciduous angiosperms, Tree Physiol., 18, 431440, 1998.

Martin, U., Pallardy, S. G., and Bahari, Z. A.: Dehydration tolerance of leaf tissues of six woody angiosperm species, Physiol. Plant., 69, 182-186, 1987.

Martínez-Vilalta, J., Poyatos, R., Aguadé, D., Retana, J., and Mencuccini, M.: A new look at water transport regulation in plants, New Phytol., 204, 105-115, 2014.

McCarthy, B. C., Vierheller, T. I., and Wistendahl, W. A.: Species ordination of upper-slope oak-hickory stands of southeastern Ohio, Bull. Torr. Botan. Club, 111, 56-60, 1984.
McCarthy, B. C., Small, C. J., and Rubino, D. L.: Composition, structure and dynamics of Dysart Woods, an old-growth mixed mesophytic forest of southeastern Ohio, Forest Ecol. Manage., 140, 193-213, 2001.

McDowell, N., Pockman, W. T., Allen, C. D., Breshears, D. D., Cobb, N., Kolb, T., Plaut, J., Sperry, J, West, A., Williams, D. G., and Yepez, E. A.: Mechanisms of plant survival and mortality during drought: Why do some plants survive while others succumb to drought?, New Phytol., 178, 719-739, 2008.

McDowell, N. G.: Mechanisms linking drought, hydraulics, carbon metabolism, and vegetation mortality, Plant Physiol., 155, 10511059, 2011.

McDowell, N. G. and Sevanto, S.: The mechanisms of carbon starvation: how, when, or does it even occur at all?, New Phytol., 186, 264-266, 2010.

McDowell, N. G., Beerling, D. J., Breshears, D. D., Fisher, R. A., Raffa, K. F., and Stitt, M.: The interdependence of mechanisms underlying climate-driven vegetation mortality, Trends Ecol. Evolut., 26, 523-532, 2011.

McDowell, N. G., Ryan, M. G., Zeppel, M. J. B., and Tissue, D. T.: Improving our knowledge of drought-induced forest mortality through experiments, observations, and modeling, New Phytol., 200, 289-293, 2013a.

McDowell, N. G., Fisher, R. A., Xu, C. G., Domec, J. C., Holtta, T., Mackay, D. S., Sperry, J. S., Boutz, A., Dickman, L., Gehres, N., Limousin, J. M., Macalady, A., Martinez-Vilalta, J., Mencuccini, M., Plaut, J. A., Ogee, J., Pangle, R. E., Rasse, D. P., Ryan, M. G., Sevanto, S., Waring, R. H., Williams, A. P., Yepez, E. A., and Pockman, W. T.: Evaluating theories of drought-induced vegetation mortality using a multimodel-experiment framework, New Phytol., 200, 304-321, 2013b.

Meinzer, F. C., Johnson, D. M., Lachenbruch, B., McCulloh, K. A., and Woodruff, D. R.: Xylem hydraulic safety margins in woody plants: coordination of stomatal control of xylem tension with hydraulic capacitance, Funct. Ecol., 23, 922-930, 2009.

Myers, B. J.: Water stress integral-a link between short-term stress and long-term growth, Tree Physiol., 4, 315-323, 1988.

Nardini, A., Battistuzzo, M., and Savi, T.: Shoot desiccation and hydraulic failure in temperate woody angiosperms during an extreme summer drought, New Phytol., 200, 322-329, 2013.

Ni, B. R. and Pallardy, S. G.: Response of gas exchange to water stress in seedlings of woody angiosperms, Tree Physiol., 8, 1-9, 1991.

Ni, B. R. and Pallardy, S. G.: Stomatal and nonstomatal limitations to net photosynthesis in seedlings of woody angiosperms, Plant Physiol., 99, 1502-1508, 1992.

Noy-Meir, I.: Desert ecosystems: environment and producers, Ann. Rev. Ecol. Systemat., 4, 25-51, 1973.

Pallardy, S. G. and Rhoads, J. L.: Morphological adaptations to drought in seedlings of deciduous angiosperms, Can. J. Forest Res., 23, 1766-1774, 1993.

Pallardy, S. G., Nigh, T. A., and Garrett, H. E.: Changes in forest composition in central Missouri: 1968-1982, Am. Midland Nat., 120, 380-390, 1988.

Pallardy, S. G., Pereira, J. S., and Parker, W. C.: Measuring the state of water in tree systems, in: Techniques and Approaches in Forest Tree Ecophysiology, edited by: Lassoie, J. P. and Hinckley, T. M., CRC Press, Boca Raton, FL, 28-76, 1991. 
Pan, Y. D., Birdsey, R. A., Fang, J. Y., Houghton, R., Kauppi, P. E., Kurz, W. A., Phillips, O. L., Shvidenko, A., Lewis, S. L., Canadell, J. G., Ciais, P., Jackson, R. B., Pacala, S. W., McGuire, A. D., Piao, S. L., Rautiainen, A., Sitch, S., and Hayes, D.: A large and persistent carbon sink in the world's forests, Science, 333, 988-993, 2011.

Phillips, O. L., Aragao, L. E. O. C., Lewis, S. L., Fisher, J. B., Lloyd, J. et al.: Drought sensitivity of the Amazon rainforest, Science, 323, 1344-1347, 2009.

Peng, C. H., Ma, Z. H., Lei, X. D., Zhu, Q. A., Chen, H., Wang, W. F., Liu, S. R., Li, W. Z., Fang, X. Q., and Zhou, X. L.: A droughtinduced pervasive increase in tree mortality across Canada's boreal forests, Nat. Clim. Change, 1, 467-471, 2011.

Porporato, A., D’Odorico, P., Laio, F., Ridolfi, L., and RodriguezIturbe, I.: Ecohydrology of water-controlled ecosystems, Adv. Water Resour., 25, 1335-1348, 2002.

Pratt, R. B., Jacobsen, A. L., Ramirez, A. R., Helms, A. M., Traugh, C. A., Tobin, M. F., Heffner, M. S., and Davis, S. D.: Mortality of resprouting chaparral shrubs after a fire and during a record drought: physiological mechanisms and demographic consequences, Glob. Change Biol., 20, 893-907, 2014.

Rice, K. J., Matzner, S. L., Byer, W., and Brown, J. R.: Patterns of tree dieback in Queensland, Australia: The importance of drought stress and the role of resistance to cavitation, Oecologia, 139, 190-198, 2004.

Rochow, J. J.: A vegetational description of a mid-Missouri forest using gradient analysis techniques, Am. Midland Nat., 87, 377396, 1972.

Rockwell, F. E., Wheeler, J. K., and Holbrook, N. M.: Cavitation and its discontents: Opportunities for resolving current controversies, Plant Physiol., 164, 1649-1660, 2014.

Schlesinger, R. C.: Fraxinus americana L. - white ash, in: Silvics of North America, Vol. 1 - Hardwoods (eds. Burns, RM, Honkala, BH), USDA Forest Service, Agriculture Handbook 654, 877 pp., 1990.

Secchi, F. and Zwieniecki, M. A.: Patterns of PIP gene expression in Populus trichocarpa during recovery from xylem embolism suggest a major role for the PIP1 aquaporin subfamily as moderators of the refilling process, Plant Cell Environ., 33, 1285-1297, 2010.

Sevanto, S., McDowell, N. G., Dickman, L. T., Pangle, R., and Pockman, W. T.: How do trees die?, A test of the hydraulic failure and carbon starvation hypotheses, Plant Cell Environ., 37, 153-161, 2014.

Sherwood, S. and Q., Fu.: A drier future?, Science, 343, 737-739, 2014.

Sperry, J. S., Hacke, U. G., Oren, R., and Comstock, J. P.: Water deficits and hydraulic limits to leaf water supply. Plant, Cell Environ., 25, 251-263, 2002.

Sun, Y., Gu, L., Dickinson, R. E., Pallardy, S. G., Baker, J., Cao, Y., DaMatta, F. M., Dong, X., Ellsworth, D., Goethem, D. V., Jensen, A. M., Law, B. E., Loos, R., Martins, S. C. V., Norby, R. J., Warren, J., Weston, D., and Winter, K.: Asymmetrical effects of mesophyll conductance on fundamental photosynthetic parameters and their relationships estimated from leaf gas exchange measurements, Plant Cell Environ., 37, 978-994, 2014.

Tardieu, F.: Will increases in our understanding of soil-root relations and root signalling substantially alter water flux models?, Philosoph. Transact. Roy. Soc. London B, 341, 57-66, 1993.
Tardieu, F. and Simonneau, T.: Variability of species among stomatal control under fluctuating soil water status and evaporative demand: modeling isohydric and anisohydric behaviours, J. Experiment. Bot., 49, 419-432, 1998.

Trenberth, K. E., Dai, A. G., van der Schrier, G., Jones, P. D., Barichivich, J., Briffa, K. R., Sheffield, J.: Global warming and changes in drought, Nat. Clim. Change, 4, 17-22, 2014.

Turner, N. C.: Correction of flow resistances of plants measured from covered and exposed leaves, Plant Physiol., 68, 1090-1092, 1981.

Tyree, M. T. and Sperry, J. S.: Do woody plants operate near the point of catastrophic xylem dysfunction caused by dynamic water stress?, Answers from a model, Plant Physiol., 88, 574-580, 1988.

van Mantgem, P. J., Stephenson, N. L., Byrne, J. C., Daniels, L. D., Franklin, J. F., Fulé, P. Z., Harmon, M. E., Larson, A. J., Smith, J. M., Taylor, A. H., and Veblen, T. T.: Widespread increase of tree mortality rates in the western United States, Science, 323, 521-524, 2009.

Voelker, S. L., Muzika, R. M., and Guyette, R. P.: Individual tree and stand level influences on the growth, vigor, and decline of red oaks in the Ozarks, Forest Sci., 54, 8-20, 2008.

Waring, R. H.: Characteristics of trees predisposed to die, Bioscience, 37, 569-577, 1987.

Weiss, J. L., Castro, C. L., and Overpeck, J. T.: Distinguishing pronounced droughts in the Southwestern United States: seasonality and effects of warmer temperatures, J. Clim., 22, 5918-5932, 2009.

Wheeler, J. K., Huggett, B. A., Tofte, A. N., Rockwell, F. E., and Holbrook, N. M.: Cutting xylem under tension or supersaturated with gas can generate PLC and the appearance of rapid recovery from embolism, Plant Cell Environ., 36, 1938-1949, 2013.

Williams, A. P., Allen, C. D., Macalady, A. K., Griffin, D., Woodhouse, C. A., Meko, D. M., Swetnam, T. W., Rauscher, S. A., Seager, R., Grissino-Mayer, H. D., Dean, J. S., Cook, E. R., Gangodagamage, C., Cai, M., and McDowell, N. G.: Temperature as a potent driver of regional forest drought stress and tree mortality, Nat. Clima. Change, 3, 292-297, 2013.

Williams, J. E., Davis, S. D., and Portwood, K. A.: Xylem embolism in seedlings and resprouts of Adenostema fasciculatum after fire, Austr. J. Bot., 45, 291-300, 1997.

Woodcock, H., Patterson, W. A., and Davies, K. M.: The relationship between site factors and white ash (Fraxinus americana L.) decline in Massachusetts, Forest Ecol. Manage., 60, 271-290, 1993.

Xu, C., McDowell, N., Sevanto, S., and Fisher, R.: Our limited ability to predict vegetation responses to water stress, New Phytol. 200, 298-300, 2013.

Yang, B., Pallardy, S. G., Meyers, T. P., Gu, L. H., Hanson, P. J., Wullschleger, S. D., Heuer, M., Hosman, K. P., Riggs, J. S., and Sluss, D. W.: Environmental controls on water use efficiency during severe drought in an Ozark Forest in Missouri, USA, Glob. Change Biol., 16, 2252-2271, 2010.

Yang, Y., Timlin, D., Fleisher, D., Kim, S.-H., Quebedeaux, B.,and Reddy, V.: Simulating leaf area of corn plants at contrasting water status, Agr. Forest Meteorol., 149, 1161-1167, 2009. 